\title{
Convict Criminology Courses at the University and in Prison
}

Stephen C. Richards, Donald Faggiani, Jed Roffers, Richard Hendrickson and Jerrick Krueger

T he Convict Criminology (CC) Perspective was first organized in the late 1990s as a means to give a voice to ex-convict criminology professors. Like many critical criminologists, ex-convict criminologists were frustrated that prison research failed to reflect the views of prisoners. The best prison studies (Sykes, 1956, 1958; Sykes and Messinger, 1960; Irwin and Cressey, 1962; Irwin, 1970, 1980, 1985) were dated and did not predict the current "imprisonment binge" (Austin and Irwin, 2001). The war on drugs became one of the primary reasons for the mass imprisonment of millions of Americans. This included a significant number of working and middle class prisoners with an interest in higher education. This led to a growing number of men and women exiting prison to enter colleges and universities. A very small number of these majored in social science disciplines, completed advanced degrees and became criminologists.

Over the last decade, the CC group has grown as more ex-cons and non-cons contribute new research to the perspective (Richards and Ross, 2001:180; Ross and Richards, 2003:6). This "new criminology" reflects research illustrating the experiences of prisoners and ex-cons, and attempts to combat the misrepresentations by scholars, the media and government. It also proposes new and less costly strategies that are more humane and effective (Richards and Ross, 2001; Ross and Richards, 2002, 2003; Jones 2003; Newbold, 2003; Terry, 2003a, 2003b). The convict scholars are able to do what many previous researchers could not - merge their prisoner past with their present to provide a provocative materialist and reflexive approach to the academic study of their field. The Convict Criminology Perspective is also based on perceptions, experiences, and analytical ideas that originate by, for and with defendants and prisoners, which are then developed by critical scholars (Richards and Ross, 2001, 2003).

The CC Perspective is now incorporated into many university courses. For example, a CC course was offered at the University of Wisconsin Oshkosh (UWO) in 2004, using a selection of books published by CC authors. Required reading included The Felon (1970), The Jail (1985) and The Warehouse Prison (2005) by John Irwin, Behind Bars (2002) and Convict Criminology (2003) by Jeffrey Ian Ross and Stephen C. Richards, The Fellas (2003) by Charles Terry, the ASC National Policy Committee article "The Use of Incarceration in the United States" by James Austin et al. (2001) and assorted issues of the Journal of Prisoners 
on Prisons. The idea was to teach an entire course based on the work of Convict Criminologists.

At the same time, UWO Criminal Justice faculty - Chris Rose, Susan Reed and Stephen Richards - organized the Inviting Convicts to College Program. Today, this program teaches a free college level CC course both fall and spring semesters at two Wisconsin state prisons (Rose et al., 2005; Richards et al., 2006). The university CC course is taught at the undergraduate and graduate level, compared to the prison courses designed as a less rigorous version at the introductory level. In this paper, we discuss the courses being taught at the university and the prisons. We then present our findings from three surveys administered to students who have completed their CC courses from both the university and prisons.

\section{Inviting Convicts to College Program: The Two Wisconsin Prisons}

Research indicates that college prison programs can help prisoners become law-abiding citizens when they return home to the community (see Lanier et al., 1994; Messemer, 2003; Welsh, 2002; Tregea, 2003). The passage of the Higher Education Act in 1965 created Basic Education Opportunity Grants (or "Pell Grants"). These grants were responsible for the creation of many Associate degree, Bachelor degree, and even Master degree programs in state and federal prisons. From 1965 to 1992, prison college programs flourished all over the country.

Then, despite these successes, Congress passed the Violent Crime Control and Law Enforcement Act of 1993, and the Higher Education Reauthorization Act of 1994, making prisoners ineligible for Pell Grants and student loans. Since 1994, no person residing in a jail or prison in the USA can qualify for a federal student grant or loan to pay for college courses. To be clear, prisoners were never allowed to receive student loans. The impact of the law was to deny them Pell Grants. Because they are incarcerated, the federal law now denies them both grants and loans.

Nevertheless, there is a few small state or federal programs that do fund individual courses at a few prisons. These programs are of limited duration and help only a small number of prisoners. Typically, they fund a technical or community college for a year or two. When the money is spent the courses are gone.

Traditionally, prisoners in the USA paid for college correspondence courses and college courses at the prison with Pell Grants. Without access to Pell Grants many could not pay for these courses. In turn, without prisoners that could pay tuition college prison programs disappeared. Today, very few prison college programs exist in the United States. 
With the support and cooperation of the Wisconsin Department of Corrections, we have implemented a new college education program in two state prisons. Members of the partnership believe that the program is successful, and we hope it is adopted widely and helps to bring college programs back to American prisons. Inviting Convicts to College prepares prisoner-students to make an informed decision about enrolling in a college or university upon their release from prison. By taking this free non-credit "college preparatory program", incarcerated students learn the academic skills required to succeed in college. The course serves as a bridge between prisons and university.

At UWO, we deploy pairs of undergraduate student interns to teach the courses at each prison. To qualify for these internships, students must first complete the $\mathrm{CC}$ course which focuses on the experiences of defendants and prisoners within the penal system. Deploying students in this fashion means universities do not incur the expense of reassigning faculty to teach the classes. The faculty members, in turn, are free to supervise a number of internships, including multiple placements of student interns in different prisons. The program is free for prisoner-students and prisons because we use students instead of professors to convene and teach the courses. Other universities may decide to use graduate students or some combination of both undergraduate and graduate students as teachers. We can envision graduate students implementing this program themselves with relatively little help from faculty.

\section{Course Content}

The course uses one textbook, Convict Criminology (2003), which is donated by the publisher. The text includes chapters authored by former prisoners who were or are now university professors. The book serves to inspire the prisoner-students and to introduce them to the Convict Criminology Perspective.

The courses are taught two hours a week, for fourteen weeks. The convict students are required to read the text, take two exams and write one paper. Midway through the course, the instructors bring college admissions and financial aid applications to the prison. They then help the convict students complete the forms. The reading helps the students to understand how higher education can transform their lives. The instructors use the reading to demonstrate how they can exit prison and become university students. Instructors also lead discussions of how students are socialized to live and work on campus. They explain how to develop good study habits, choose a major and become serious students. A number of former prisoners who have completed this course, including 
one of the authors of this paper, have already started their studies at several University of Wisconsin campuses.

\section{Certificate of Completion}

Upon finishing the courses, the prisoner-students receive a certificate of completion signed by the Dean of the University and prison administrators. The students do not receive university credits for completing the course. However, the certificate does indicate that they may be prepared for academic success at the university. During the first four years of the program, we believe the certificate has helped a number of former prisoners gain admission to university.

Before their release from prison the prisoners had officially qualified for admission and financial aid. Their "release plan" from the prison included attending college or university where their financial aid checks were waiting. The typical student aid award was $\$ 10,000-12,000$ for the year. Convict students show their certificates of completion, letters of acceptance, and student aid awards to their cellmates at the prisons, and this, in turn, inspired more prisoners to sign-up for the course. We now have long waiting lists at each prison. At the men's medium security prison nearly 100 prisoners have requested the course.

Upon arrival at the university the student aid office deducted their tuition, room, and board, and gave them the remainder. The former prisoners are now university students living in dormitories, with meal tickets and tuition paid. This means they will not be homeless, sleeping on park benches, eating in soup kitchens or in other situations where they would be easy prey for police to arrest and return to prison.

\section{Convicts as "Invisible Minorities"}

The Convict Criminology movement suggests that prisoners, like anyone else, have the potential to be good students. "Non-traditional" (older) students now make up a growing population on many college campuses. These are older men and women pursuing higher education later in life, often times following the decision to make a career change, divorce, military service or stretch in prison. In our experience, we have found former prisoners and parolees to be high performing students who are committed to their studies.

Today, university administrators commonly discuss affirmative action and the need for diversity. Meanwhile, many college campuses are nearly exclusively white, while prison populations are disproportionately black 
and brown. Universities that are seriously concerned about attracting minority students should look to their nearby prison. In prisons, they will find many minority men and women waiting for an invitation to remake their lives with the help of higher education.

We call ex-convict students "invisible minorities" because while university admissions committees cannot identify prisoners by skin colour, they nonetheless suffer legally prescribed discrimination (see Travis, 2002). Some universities openly discriminate against convicted felons to deny admission, student aid, campus employment and housing. Some admissions applications even include "felony questions". Most schools of social work, medicine, nursing, law and business deny admission to applicants with felony convictions. Some go so far as to deny admission to persons with misdemeanour convictions.

Despite these discriminations, we view universities and prisons in many ways as parallel institutions. Most are state funded. Even private colleges and prisons depend on taxpayer monies. Further, college campuses and prisons often exist in close proximity, depend on the same public resources and operate in the same communities. In fact, some prisons are located very close to universities. Moreover, both institutional populations are similar in that they both consist of young men and women in need of training and education.

\section{Correctional Education and Recidivism}

Taxpayers want state employees to discover new ways to provide services without additional taxes. Universities and prisons working together to reduce recidivism and helping prisoners to become productive citizens is one way we can all serve the community. Early research on the benefits of education and its impact on reducing recidivism were far from conclusive, often showing mixed or contradictory results (see Martinson, 1974; Palmer, 1976). However, these earlier studies helped to shape the debate on correctional education by raising issues about the utility of such programs.

More recent research on the utility of correctional education programs has consistently shown reductions in recidivism or the length of time for recidivism for those completing a correctional education program while incarcerated. For example, the Correctional Education Association conducted a three-state (Maryland, Ohio and Minnesota) study examining the recidivism rate of a release cohort in excess of 3100 prisoners over a three year period. The study divided the group into those who participated in a correctional education program while incarcerated and those who did 
not participate. Their findings show a 29 percent overall reduction in the recidivism rate for the group who participated in correctional education versus those that did not participate.

Batiuk et al. (2005) used a quasi-experimental design to assess the impact of different correctional education programs on recidivism. Using a cohort of prisoners released from prison between 1989 and 1992 in the State of Ohio, they disaggregated their cohort into two main groups - those who participated in correctional education and those who did not. They further subdivided the participating group into the four different correctional education programs offered within the institution: 1) General Equivalency Diploma; 2) high school; 3) vocational; and 4) college. They followed this cohort of prisoners through 2003, nearly 13 years after their initial release, to determine if they recidivated (by committing a new offense or if they had their parole revoked) and the length of time from release to recidivism. Incorporating an event history analysis, the authors calculated a "recidivism hazard" rate, essentially defining the odds ratio of recidivism. Their results indicate that compared to the non-participating cohort there was a 62 percent reduction in the recidivism hazard rate for those who participated in a college level correctional education program. With these successes in mind, it makes little sense to turn to imprisonment, especially devoid of robust education programs, to address crime when it costs the state less to support one college student than return a man or woman to prison (Steurer and Smith, 2003).

\section{Evaluating the Program}

\section{The Two Prisons}

We have been teaching the Inviting Convicts to College Program inside Wisconsin state prisons for four years, once during the fall and again in the spring semesters. The courses are now taught at two state prisons, one for men and one for women. Oshkosh Correctional Institution (OCI) is a medium security prison for men. OCI presently has a rated bed capacity of 1,494 with a prisoner count that exceeds 2,000 . This institution has no college prison program. Taycheedah Correctional Institution (TCI) is a maximum and medium security facility for women with a prisoner count of nearly 700. It is the primary prison for women in Wisconsin. This institution also has no college prison program. OCI is located 5 miles from the UWO campus, while TCI is 20 miles away. 


\section{The Three Surveys}

The purpose of this research is primarily exploratory. The survey consisted of 10 questions with fixed or closed-ended responses, followed by several open-ended questions. The questions asked students what they thought of the course and the Convict Criminology Perspective. The prisoners responded to the closed-ended questions (the value, quality and usefulness of the courses) and their views are reflected in their written responses to the open-ended questions.

For this report, we decided not to analyze the closed-ended responses, as the number of respondents is small $(\mathrm{n}=30)$. Instead, we decided to present their written responses to the open-ended questions. We decided that their answers were more interesting than our 10 questions. Clearly, the students wanted to express themselves without the constraints of our questions.

The survey was distributed to each of the three classes at the end of the course. We used a simple convenience sample. We were not able to draw a random representative or stratified sample. As the number of respondents is very small $(n=30)$, our findings cannot be used to generalize to a larger population. Table 1 shows the number of responses from each of the three institutions, as well as the average age and age range for each of the classes. The average sentence and sentence range is also included for the students from the two correctional institutions.

Table 1: Demographics for survey respondents

\begin{tabular}{|l|c|c|c|}
\cline { 2 - 4 } \multicolumn{1}{c|}{} & $\begin{array}{c}\text { Oshkosh } \\
\text { Correctional } \\
\text { Institution }\end{array}$ & $\begin{array}{c}\text { Taycheedah } \\
\text { Correctional } \\
\text { Institution }\end{array}$ & $\begin{array}{c}\text { University of } \\
\text { Wisconsin } \\
\text { - Oshkosh }\end{array}$ \\
\hline Number of responses & 8 & 6 & 16 \\
\hline Average age of respondents & 29.25 & 24.25 & 22.13 \\
\hline Age range of respondents & $23-45$ & $16-30$ & $20-27$ \\
\hline Average sentence (in months) & 60.63 & 82.8 & N/A \\
\hline Sentence range (in months) & $15-150$ & $48-144$ & N/A \\
\hline
\end{tabular}




\section{The Student Responses}

We have organized our report of the surveys by group, first the UWO students, then the male prisoners, followed by the female prisoners. The responses of each group are organized around different themes. We briefly introduce each theme and offer commentary as a means to tie the responses together analytically.

In general, the university students and prisoners (male and female) approached the subject matter from different standpoints. The university students took the course and read the books as a means to think their way into the study of prison and prisoners. In contrast, the prisoners used the course to plan their way out of the prison. They understood that Convict Criminology was about transformation and planning a journey that might take them out of prison and into college. The female prisoners demonstrated the most critical understanding of the course readings.

\section{The UWO Students}

The university students report that the Convict Criminology course was very different from their other college courses. Two university students wrote that the course offered a different way of looking at the criminal justice system:

I appreciate a different way of looking at the criminal justice system and those individuals under managerial jurisdiction (27 year old male UWO student).

The course is a great learning tool that offers a different viewpoint normally not discussed within criminal justice courses (21 year old male UWO student).

Two other students found the course less boring than most:

This course breaks the monotony of our normal one-sided courses (22 year old male UWO student).

For the most part, the readings were written with a lot of emotion and integrity that you don't find many places. It was a pleasant change from the mindless drawl usually found in criminal justice textbooks (21 year old male UWO student). 
The university students understood the course as unique. They found the reading, class presentations and connection with the prison kept them interested. As a result of this unique course, the university students learned to view prisons and prisoners from a new perspective. One male university student wrote how it opened his eyes:

[The course] opened my eyes to the harmful effects felt by convicts while imprisoned and after release that are perpetuated by the system (21 year old male UWO student).

One university student said it gave him another view of the prison system:

I felt that Convict Criminology was a very valuable class for me. I felt that the books I read had a very different take on the correctional system. It was good to have another side of the story. I think that a person who wants to study the criminal justice system would be selling themselves short if the only information they were given was from the outside. I felt that this class gave me another view of the system. I feel that I have a more complete understanding of the system than I did before this class (22 year old female UWO student).

The course helped the university students to better understand the prisoner point of view. Reading Convict Criminology Perspective authors and an issue of the Journal of Prisoners on Prisons, was the first time they read what prisoners and former prisoners thought about prisons.

The CC Perspective was both educational and transformative for the university students, who reported that the course changed their own views of prisons and corrections. Reading about convicts that become professors helped one UWO student to consider a career in corrections:

It [the course Convict Criminology] has caused me to give more thought toward a career in corrections...in a positive sense that is (27 year old male UWO student).

The course reminded another university student not to be so judgmental:

The course reminded me not to be so quick to judge and that there are a multitude of ways a person can end up behind bars (27 year old male UWO student). 
A third student heard the voices of the convict authors in the books:

I think this course was very valuable for me in many different ways. For example, it gave prisoners a voice and humanized them in a way that I have never encountered. For those naïve students who view prisoners as vile monsters, their opinions must have changed also. Finally, it helped me empathize with prisoners' situations (21 year old male UWO student).

The transformation of convicts into professors taught the students to think of prisoners as human being, rather than categories. They began to consider how people change over the course of their lives.

The university students enjoyed reading about ex-convicts becoming professors. These criminal justice students began to appreciate how difficult it is for ex-convicts to be accepted in academia. They appeared especially interested in the struggles ex-convicts have once they are professors.

I enjoyed reading about the struggles faced by ex-convicts in trying to secure a place of employment within academic settings. I know Dr. Richards [UWO ex-convict criminal justice professor, and internship supervisor] and Dr. Jones [ex-convict Marquette University criminology professor, and guest speaker] discussed it, and it really gave life to the struggle of ex-cons (21 year old male UWO student).

Another university student was amazed that an ex-convict could become a professor:

The class was interesting because this is a subject within the criminal justice system that is typically not addressed. The idea of ex-convicts becoming instructors and professors following lengthy prison sentences is absolutely amazing. It is as if they [Convict Criminologists] are the light at the end of the tunnel (22 year old male UWO student).

The strength of the Convict Criminology Perspective is former prisoners using social science research tools and methods to reinterpret what they observed and lived in prison. As former convicts trained to do science, they see their prison time as an extended participant observation or forced ethnographic experience. At the very least, their years in prison 
provides a more accurate picture of what happens inside the correctional institution or penitentiary. The autobiographical accounts in Convict Criminology can be very compelling reading for a criminal justice student. One university student was impressed by the validity of the information he read in the assigned books:

No one except the Convict Criminologists would be able to provide us valid information about being a convicted felon. Therefore, their input is the most accurate one can receive ( 22 year old male UWO student).

The Convict Criminology course provided a space where university students learned about criminality by reading literature written by people who have experienced the criminal justice system first hand. One university student reflected on the need for more alternatives to prison:

One thing I learned from the course is that we need to find alternatives to locking up non-violent offenders up. They pose no threat to society in a harmful way. Our resources would be better used if redirected elsewhere (23 year old male UWO student).

Another student commented on the content of the course:

I think that the interesting content of this course is something that the vast majority of people don't have a clue about. I think that more people should be exposed to this information (22 year old male UWO student).

A third student was sceptical at first and then came to see the experience as valuable, even eye-opening:

I was rather sceptical in the beginning of the course and even thought the first few weeks, that I didn't see the point of this "new criminology". The straight-forward writings and opinions of the authors made it a valuable experience... Most of all the course reading was very "page-turning." Incorporating criminology with real life success stories really worked well... I felt this class opened our eyes to a new side of criminology. This course strays from the conventional views of what criminology is limited to. When we can study every aspect of the science, we can truly understand it (22 year old student). 
At the very least, the student responses suggest that they understood Convict Criminology as a new criminology, different from what they read in other courses. A number of them liked reading about real life success stories.

The university students report that they want the courses to continue at both the university and two prisons. As we have two ex-convict professors in our department, the Convict Criminology course will continue at the university. The collaboration between university faculty and the prisons is always subject to challenges. For example, some politicians may not like prisoners receiving a free college level course. One female university student understood that some of her fellow students were the instructors at the two prisons. She liked the fact that course was helping prisoners:

I believe the course gives great insight to people outside the system to what goes on inside. Also what the class is doing for people inside [prison] is great (22 year old female UWO student).

A male university student wrote that the course should continue both at the university and the prisons:

This class needs to continue for students and prisoners. This may be one of few chances to help people succeed in a system that focuses on failure (22 year old male UWO student).

This small sample of relatively conservative criminal justice students gave no overtly negative comments on the questionnaire. The university course appears to be popular with students. Still, we understand that some students might want to keep their concerns or complaints to themselves.

\section{The Oshkosh Correctional Institution Male Prisoners}

The prisoners from OCI were equally enthusiastic about the course. They looked forward to the class every week. The course gave them hope they could still be "somebody" one day:

This course made me realize that being a convicted felon doesn't mean that you can't succeed ( 29 year old male prisoner).

A second prisoner elaborated on accomplishing something, hope and believing that somebody cares about them: 
I would recommend this class to anyone doing some time. It gives you feelings of accomplishing something. It might kick start some others to look at furthering their education. It would be terrible to stop offering this class. This class gives the hopeless individuals some hope. Nobody cares about our future and this class is offering some hope (45 year old male prisoner).

Many prisoners have both a bleak past and potential future. After many years in prison, these men suffer from clinical depression. They have few reasons to believe that anybody cares about them. The course gives the prisoners some reason to think they can improve their lives and inspired them to plan a new future through higher education. Completion of the course shows them they could be successful at university. The class reading introduced them to the study of criminology. The textbook demonstrated that they were not alone:

I've seen and understand I'm not alone and the struggles I've faced are similar to others in the Convict Criminology text. I'm inspired to see that others became successful after serving time in prison (30 year old male prisoner).

The course inspired them to apply for admission to university:

This course has been very valuable not only because it has shown me what a college course is like, it has also taught me lot about criminology which has become very interesting to me (31 year old male prisoner).

The course inspired me to go to college (23 year old male prisoner, now enrolled at UWO).

The program has inspired a number of male prisoners to go to college. Some of these men are completing their undergraduate degrees at different universities in Wisconsin.

\section{Taycheedah Correctional Institution Female Prisoners}

Out of all the respondents, TCI prisoner-students offered the most sophisticated commentary about the corrupt prison system. To think through the course content they referred to a number of recent lawsuits, newspaper articles and court decisions related to conditions at the prison: 
So many people know of the corruption and yet so little is being done to help (27 year old female prisoner).

The course let me know that at least someone was looking at the real prison system. And the actual truth behind how they are really run. Nobody really hears how it really is behind razor wire, only what political heads want them to ( 28 year old female prisoner).

...this course was very valuable because a lot of things I felt were confirmed. I sometimes felt that the concerns I had involving politics, the government, the D.O.C. system as well as police officials, and federal agents were probably a case of paranoia due to the race issues and the discrimination towards convicts ( 30 year old female prisoner).

These responses suggest the female prisoners have many serious concerns about prison conditions. Some of these were male officers raping their cellmates, the lack of adequate medical attention and suicides.

The course inspired the women to continue their formal education. Three of the female convicts responded:

I would absolutely recommend this course to a friend, especially the women I've met in prison (30 year old female prisoner).

The course is very inspiring to a lot of people (16 year old female prisoner).

The class has proven to me that even though I am a felon and am in prison, that when I get released, I can still go to college and become successful (24 year old female prisoner).

They especially liked reading about convicts becoming professors. Each of the autobiographical chapters in the book focuses on day-to-day life in different prisons:

The reading material was more easy to get into because it's a topic that all of us on the inside can relate to, which really makes it almost absolute that we would all be interested ( 28 year old female prisoner).

The interest level is very high on my part because I'm here, and people very close to me are in prison as well, so this subject hits 
the bull's-eye when it comes to present day life (28 year old female prisoner).

The course encouraged the women to continue their formal education. Every semester a number of the women exit prison to enter technical schools, community colleges or university. Following their experience with the course, many women prisoners wanted to join the larger Convict Criminology movement. They clearly had a deeper understanding of the importance of $\mathrm{CC}$ as a political statement and activist agenda:

But to know that I can become more than I expected as an ex-con is very encouraging ( 30 year old female prisoner).

I am very excited to know that there is a whole world of successful ex-cons who are willing to help me be all that I can in the event of striving to excel and that they will allow me to stand with them to make a change for those who are and have been incarcerated (30 year old female prisoner).

One woman wants to be a professor or researcher:

I plan to be a part of this criminology movement and maybe become a professor or some kind of researcher (30 year old female prisoner).

Another woman understood that the movement was about giving prisoners a voice:

I wish the findings throughout this course could be used to help make a stand and statement to the rest of the world about how bad the criminal justice system really is. Because those of us on the inside have voices that could prove very valuable, and we need to be heard ( 28 year old female prisoner).

Compared to the university students and male prisoners, the female prisoners were more likely to understand Convict Criminology as a movement they could join.

\section{Conclusion}

In this paper we have discussed the Convict Criminology perspective, the state construction of convicts as "invisible minorities" and the overall impact of correctional education on recidivism. In order to combat the 
racial divide in higher education and provide those incarcerated with the tools to reintegrate successfully upon their release from prison, we outlined our Inviting Convicts to College Program. Ideally, more universities could go to prisons and offer non-credit college level courses. At the very least, they could send staff every semester to local prisons to assist the men and women to complete admission and financial aid forms. They could also provide academic advisors that were trained to counsel former prisoners on their campuses. Finally, they might consider ways to make their university a welcome place for formerly incarcerated men and women.

Prisons warehouse men and women that desperately need higher education to remake their shattered lives and to overcome the legal discrimination they face. One way we can help prisoners overcome the obstacles they face is to invite and support their efforts to enter college. We are prepared to help if you decide to begin your own program.

\section{REFERENCES}

Austin, James, Marino A. Bruce, Leo Carroll, Patricia L. McCall and Stephen C. Richards (2001) "The Use of Incarceration in the United States: ASC National Policy Committee White Paper", Critical Criminology, 10(1): 17-41.

Austin, James and John Irwin (2001) It's about Time, Belmont (CA): Wadsworth.

Batiuk, Mary E., Karen F. Lahm, Matthew McKeever, Norma Wilcox and Pamela Wilcox (2005) "Disentangling the Effects of Correctional Education: Are Current Policies Misguided? An Event History Analysis", Criminal Justice, 5(1):55-74.

Irwin, John (2005) The Warehouse Prison: Disposal of the New Dangerous Class, Los Angeles: Roxbury.

Irwin, John (1985) The Jail, Berkeley: University of California Press.

Irwin, John (1980) Prisons in Turmoil, Boston: Little, Brown.

Irwin, John (1970) The Felon, Englewood Cliffs (NJ): Prentice-Hall.

Irwin, John, and Donald Cressey (1962) "Thieves, Convicts and Inmate Culture", Social Problems, 10: 142-155.

Jones, Richard S. (2003) "Excon: Managing a Spoiled Identity", in J. I. Ross and S. C.

Richards (eds.), Convict Criminology, Belmont (CA): Wadsworth, pp. 191-208.

Lanier, Charles S., Susan Philliber and William W. Philliber (1994) "Prisoners with a Profession: Earning Graduate Degrees Behind Bars", Journal of Criminal Justice Education, 5(1):15-29.

Martinson, Robert (1974) "What Works? - Questions and Answers about Prison Reform", The Public Interest, 35: 22-54.

Messemer, Jonathan E. (2003) "College Programs for Inmates: The Post-Pell Grant Era", Journal of Correctional Education, 54: 32-39.

Newbold, Greg (2003) "Rehabilitating Criminals: It Ain't That Easy", in J. I. Ross 
and S. C. Richards (eds.), Convict Criminology, Belmont (CA): Wadsworth, pp. 150-169.

Palmer, T. (1976) "Martinson Revisited", in R. Martinson, T. Palmer and S. Adams (eds), Rehabilitation, Recidivism, and Research, Hackensack (NJ): National Council on Crime and Delinquency, pp. 41-61.

Richards, Stephen C., Chris D. Rose and Susan O. Reed (2006) "Inviting Convicts To College: Prison and University Partnerships", in The State of Corrections: 2005 Proceedings ACA Annual Conferences, Lanham (MD): American Correctional Association, pp. 171-180.

Richards, Stephen C. and Jeffrey I. Ross (2001) "The New School of Convict Criminology", Social Justice, 28(1): 177-190.

Rose, Chris D., Susan O. Reed, and Stephen C. Richards (2005) "Inviting Convicts To College: A Free College Preparatory Program For Prisoners", Offender Programs Report, 8(6): 81, 91-93.

Ross, Jeffrey I. and Stephen C. Richards (eds.) (2003) Convict Criminology, Belmont (CA): Wadsworth.

Ross, Jeffrey I. and Stephen C. Richards (2002) Behind Bars: Surviving Prison, New York: Alpha/Penguin.

Steurer, Stephen J. and Linda G. Smith (2003) Education Reduces Crime: Three-State Recidivism Study, Executive Summary, Washington, D.C.: Correctional Education Association, The United States Department of Correctional Education.

Sykes, Gresham M. (1958) The Society of Captives: A Study of A Maximum Security Prison, Princeton (NJ): Princeton University Press.

Sykes, Gresham M. (1956) "Men, Merchants, and Toughs: A Study of Reactions to Imprisonment", Social Problems, 4: 130-138.

Sykes, Gresham M. and Sheldon L. Messinger (1960) "Inmate Social System", in R. A. Cloward, D. R. Cressey, G. H. Grosser, R. H. McCleery, L. E. Ohlin, G. M. Sykes and S. L. Messinger (eds.), Theoretical Studies in Social Organization of the Prison, New York: Social Science Research Council, pp. 5-19.

Terry, Charles M. (2003a) The Fellas: Overcoming Prison and Addiction, Belmont (CA): Wadsworth.

Terry, Charles M. (2003b) "From C-Block to Academia: You Can’t Get There From Here", in J. I. Ross and S. C. Richards (eds.), Convict Criminology, Belmont (CA): Wadsworth, pp. 95-119.

Travis, Jeremy (2002) "Invisible Punishment: An Instrument of Social Exclusion", in M. Mauer and M. Chesney-Lind (eds.), Invisible Punishment: The Collateral Consequences of Mass Imprisonment, New York: The New Press, pp. 15.36.

Tregea, William S. (2003) "Twenty Years Teaching College in Prison”, in J. I. Ross and S. C. Richards (eds.), Convict Criminology, Belmont (CA): Wadsworth, pp. 309-324.

Welsh, Michael (2002) "The Effects of the Elimination of Pell Grant Eligibility for State Prison Inmates”, Journal of Correctional Education, 53: 154-158. 


\section{About the Authors}

Stephen C. Richards is an Associate Professor of Criminal Justice at the University of Wisconsin Oshkosh. His most recent books include Behind Bars (2002), Convict Criminology (2003) and Beyond Bars (2009) with Jeffrey Ian Ross. Richards is a Soros Senior Justice Fellow.

Donald Faggiani is an Assistant Professor of Criminal Justice at the University of Wisconsin Oshkosh. He received his Ph.D. from the University of Illinois Chicago in Political Science/Public Policy Analysis.

Jed Roffers graduated from the University of Wisconsin Oshkosh with a Bachelors in Criminal Justice (2008). He is now a Wisconsin State Trooper.

Richard Hendricksen is a former Wisconsin prisoner. He is now a Criminal Justice student at the University of Wisconsin Oshkosh.

Jerrick Krueger is a Criminal Justice student at the University of Wisconsin Oshkosh.

\section{Program Information}

For more information about Convict Criminology and the Inviting Convicts to College Program contact:

Dr. Stephen C. Richards, Associate Professor Department of Public Affairs, Criminal Justice Program

University of Wisconsin Oshkosh 800 Algoma Blvd.

Oshkosh, WI 54901-8655

e-mail: richarsc@uwosh.edu

websites:

http://www.uwosh.edu/departments/public_affairs/

http://www.convictcriminology.org/ 